American Political Science Association

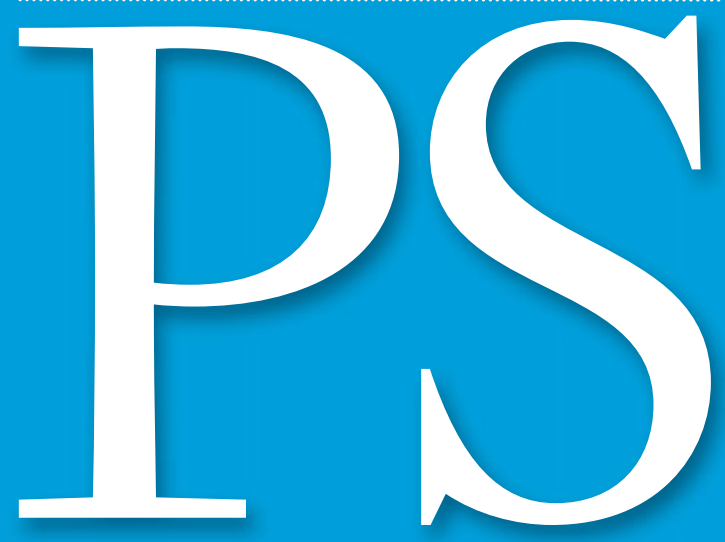

Political Science \& Politics O с товев 2015 , Vol U me 48 , N U m B e 4
Reviewer Fatigue? Why Scholars Decline to Review Their Peers' Work Marijke Breuning, Jeremy Backstrom, Jeremy Brannon, Benjamin Isaak Gross, Michael Widmeier

Why, and How, to Bridge the "Gap" Before Tenure: Peer-Reviewed Research May Not Be the Only Strategic Move as a Graduate Student or Young Scholar Mariano E. Bertucci

Partisan Politics and Congressional Election Prospects: Evidence from the Iowa Electronic Markets Joyce E. Berg, Christopher E. Peneny, and Thomas A. Rietz
I'VE BEEN ASKED TO REVIEW THIS PAPER. CAN YOU DO IT?

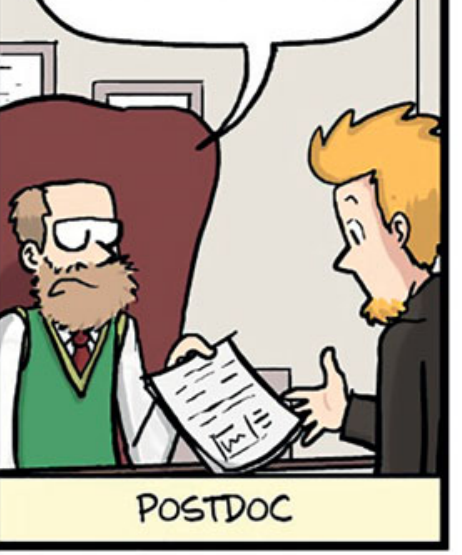

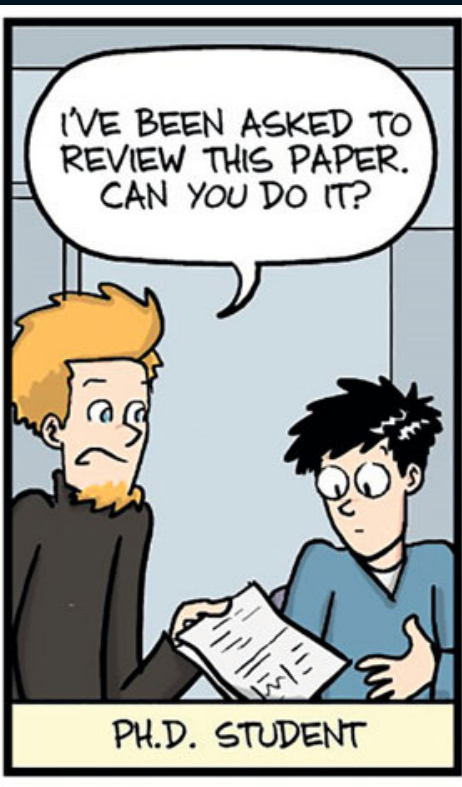

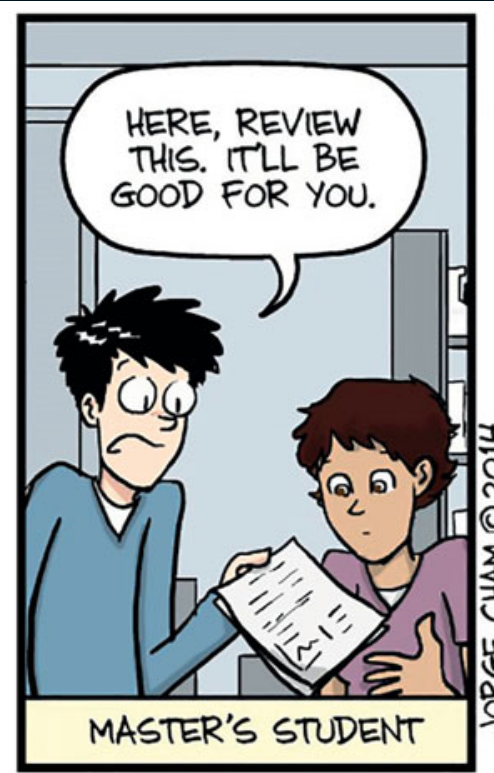

THE ACADEMIC REVIEW PROCESS

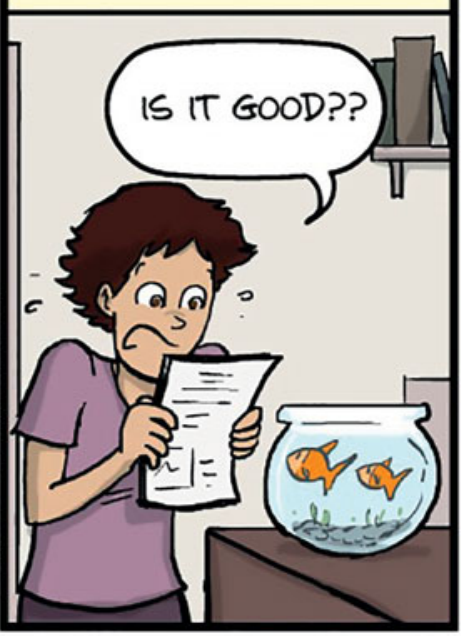




\section{SAVE THE DATE}

\section{APSA 2016 Teaching \& Learning Conference}

Portland, Oregon - Marrriot Portland Waterfront

February 12-14, 2016

Visit www.apsanet.org/tlc to learn more!

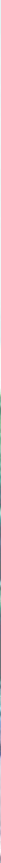

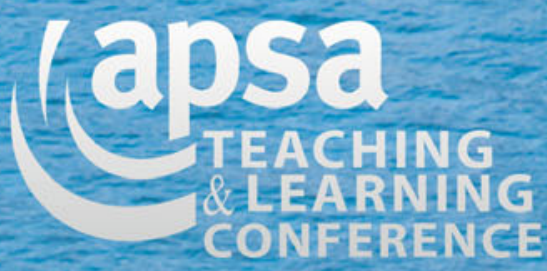




\section{EDITORS' CORNER}

FEATURES

THE PROFESSION

THE TEACHER
571 Phillip Ardoin and Paul Gronke

573 Partisan Politics and Congressional Election Prospects: Evidence from the Iowa Electronic Markets Joyce E. Berg, Christopher E. Penney, and Thomas A. Rietz

579 Forecasting Congressional Elections Using Facebook Data Matthew C. MacWilliams

584 I Approve This Candidate: The Strategic Use of Ad Endorsements in the 2008 Election

Newly Paul and Chance York

591 Why, and How, to Bridge the "Gap" Before Tenure: Peer-Reviewed Research May Not Be the Only Strategic Move as a Graduate Student or Young Scholar Mariano E. Bertucci

595 Reviewer Fatigue? Why Scholars Decline to Review their Peers' Work

Marijke Breuning, Jeremy Backstrom, Jeremy Brannon, Benjamin Isaak Gross, and Michael Widmeier

601 Teaching Policy Analysis Through Animated Films: A Mickey Mouse Assignment?

Valerie Cooley and Andrew Pennock

607 Flipping the Introductory American Politics Class: Student Perceptions of the Flipped Classroom

Shannon Jenkins

612 The "Crossfire Approach": Attracting Political Science Majors in Large-Lecture Sections of Introductory Courses

Jody C Baumgartner and Jonathan S. Morris

617 The Political Is Personal: Using Political Life Narratives to Engage Students

Sarah Combellick-Bidney

621 Fantasy Presidents: A Game That Makes Research More Exciting Dave Bridge

626 Simulating the Bargaining Model of War Kyle Haynes

630 We Still Need You! An Update on the Status of K-12 Civics Education in the United States

Wayne Journell

635 Campus Teaching Awards, Academic Year 2014-15

PEOPLE 639 Including news about Francis Fukuyama, Andrea Louise Campbell, Terri Givens, Brock Tessman, Lisa Anderson, Sarah A. Binder, Timothy J. Feddersen, Martin Gilens, Sally Haslanger, Douglas Rivers, David Stasavage, Kathleen Thelen, and others 
646 In Memoriam: Philip E. Converse, Byron W. Daynes, Jay Goodman, Jack W. Peltason, Joseph A. Schlesinger, and Benjamin W. Smith

ASSOCIATION NEWS

655

662

666

668

671
Jennifer Hochschild: Academic Extrovert Anthony King

Highlights from the PS Editors' Report

66 Nominations Accepted for the 2016 APSA Officers and Council, Awards, and Committees

Briefs

Congressional Fellowship Program: Practice and Theory:

How Experiencing the Political Process Can Inform

Scholarship

Laura Blessing 


\section{DEPARTMENTS}

639 People

655 Association News

674 International

676 Gazette

687 Annual Meeting 2015
EDITORS: Phillip Ardoin, Appalachian State University Paul Gronke,

Appalachian State University and Reed College

MANAGING EDITOR: Celina Szymanski

EDITORIAL ASSISTANTS: Drew Meadows Chelsey Meade

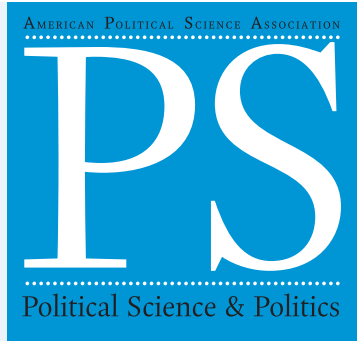

EDITORIAL BOARD:

Matthew R. Cleary, Syracuse University; Heath Fogg Davis, Temple University; Diana Evans, Trinity College; Rodolfo Espino III, Arizona State University; Jennifer Gandhi, Emory University; Matthew Hindman, Arizona State University; Liesbet Hooghe, University of North Carolina, Chapel Hill; Jennifer Jerit, Stony Brook, SUNY; Alisa Kessel, University of Puget Sound; Ari Kohen, University of Nebraska, Lincoln; Kathryn C. Lavelle, Case Western Reserve University; Lori Marso, Union College; Rose McDermott, Brown University; Ronald J. Schmidt, Sr., California State University, Long Beach; and Catherine Warrick, Villanova University.

\section{ASSOCIATION OFFICE ADDRESS AND MEMBERSHIP INFORMATION:}

American Political Science Association individual membership dues are: regular members with income $\$ 200,000+, \$ 320 ;$ \$135,000-199,999, \$271; \$100,00o-134,00o, \$241; \$80,00o-99,999, \$207; \$6o,ooo-79,999, \$186; \$50,000-59,999, \$170; \$40,000-49,999, \$145; under \$40,ooo, \$98; retired members $\$ 25,000+, \$ 66$; retired under $\$ 25,000, \$ 40$; targeted international member (TIM), \$40; life member, \$3,0oo; associate member, one journal, \$62; high school teacher (PS only), \$45; student member, \$45; unemployed member, $\$ 45$. The amount of the dues allocated for a subscription is $\$ 5.75$ for an individual membership.

Changes of address for members should be completed online or mailed to the APSA membership office at: APSA, 1527 New Hampshire Avenue, NW, Washington, DC 20036-1206.

\section{SUBSCRIPTION, PUBLISHING, AND ADVERTISING OFFICE ADDRESS:}

Cambridge University Press, 32 Avenue of the Americas, New York, NY 10013-2473; and (outside North America) Cambridge University Press, University Printing House, Shaftesbury Road, Cambridge CB2 8BS, England.

SUBSCRIPTION INFORMATION: PS: Political Science \& Politics (ISSN 1049-0965) is published in January, April, July, and October by Cambridge University Press for the American Political Science Association. Annual institutional electronic-only subscription rate (2015) is US\$1119 in the United States, Canada, and Mexico, UK£625 elsewhere. Annual institutional printand-electronic subscription rate (2015) is US\$1297 in the United States, Canada, and Mexico, $U K £ 716$ elsewhere. Periodicals postage rate paid at New York, NY, and additional mailing offices. POSTMASTER: Address changes should be sent to: PS: Political Science \& Politics, Cambridge University Press, 100 Brook Hill Drive, West Nyack, NY 10994-2133, USA.

Copyright (C) 2015 by the American Political Science Association. All rights reserved. No part of this publication may be reproduced, in any form or by any means, electronic, photocopying, or otherwise, without permission in writing from Cambridge University Press. Photocopying information for users in the USA: The Item-Fee Code for the publication (1049-0965/15 $\$ 15.00+\$ .10)$ indicates that copying for internal or personal use beyond that permitted by Sec. 107 or 108 of the U.S. Copyright Law is authorized for users duly registered with the Copyright Clearance Center (CCC) Transaction Reporting Service, provided that the appropriate remittance of \$15.0o per article is paid directly to CCC, 222 Rosewood Drive, Danvers, MA 01923. Specific written permission must be obtained for all other copying. ADVERTISING: $P S$ has a circulation of 16,000 . Please contact our Advertising Sales Team at USAdSales@cambridge.org for full advertising information including rates and specs.

compositıon: TNQ Books and Journals Pvt. Ltd., Chennai, India. PRINTING AND DISTRIBUTION: Dartmouth Printing Co., Hanover, NH. 


\section{About APSA}

Founded in 1903, the American Political Science Association is the leading professional organization for the study of political science and serves more than 15,000 members in over 80 countries. With a range of programs and services for individuals, departments, and institutions, APSA brings together political scientists from all fields of inquiry, regions, and occupational endeavors within and outside academe in order to expand awareness and understanding of politics.

The direct advancement of knowledge is at the core of APSA activities. We promote scholarly communication in political science through a variety of initiatives including publishing three distinguished journals: American Political Science Review, Perspectives on Politics, and PS: Political Science and Politics.

\section{Officers}

\section{PRESIDENT}

Rodney E. Hero

University of California, Berkeley

\section{PRESIDENT-ELECT}

Jennifer Hochschild

Harvard University

\section{VICE-PRESIDENTS}

E. J. Dionne, Jr.

Georgetown University

Brookings Institution

Joanne Gowa

Princeton University

Fredrick C. Harris

Columbia University

\section{TREASURER}

Kathleen Thelen

Massachusetts Institute of Technology

\section{SECRETARY}

Linda L. Fowler

Dartmouth College

\section{PROGRAM CO-CHAIRS}

Layna Mosley

University of North Carolina,

Chapel Hill

Alvin Bernard Tillery

Northwestern University

\section{EDITOR-IN-CHIEF, APSR}

John Ishiyama

University of North Texas

\section{EDITOR-IN-CHIEF,} PERSPECTIVES

Jeffrey C. Isaac

Indiana University

\section{EXECUTIVE DIRECTOR}

Steven Rathgeb Smith

American Political Science Association

\section{Council}

\section{3-2015}

Amrita Basu

Amherst College

Kenneth R. Benoit

London School of Economics

Christine Di Stefano

University of Washington

James N. Druckman

Northwestern University

Hank C. Jenkins-Smith

University of Oklahoma

David C. Kang

Universtiy of Southern California

John M. Sides

George Washington University

Evelyn M. Simien

University of Connecticut

\section{4-2016}

Michelle D. Deardorff

University of Tennessee,

Chattanooga

Maria C. Escobar-Lemmon

Texas A \& M University

Frances E. Lee

University of Maryland, College

Park

David Lublin

American University

Marc Lynch

George Washington University

Tasha Philpot

University of Texas, Austin

David Stasavage

New York University

Mark E. Warren

University of British Columbia

Former APSA Presidents

Frank J. Goodnow

Albert Shaw

Frederick N. Judson

James Bryce

A. Lawrence Lowell

Woodrow Wilson

Simeon E. Baldwin

Albert Bushnell Hart

W. W. Willoughby

John Bassett Moore

Ernst Freund

Jesse Macy

Munroe Smith

Henry Jones Ford

Paul S. Reinsch

Leo S. Rowe

William A. Dunning

Harry A. Garfield

James W. Garner

Charles E. Merriam

Charles A. Beard

William Bennett Munro

Jesse S. Reeves

John A. Fairlie

Benjamin F. Shambaugh

Edward S. Corwin

William F. Willoughby

Isidor Loeb

Walter Shepard

Francis W. Coker

Arthur N. Holcombe

Thomas Reed Powell

Clarence A. Dykstra

Charles Grove Haines

Robert C. Brooks

Frederic A. Ogg

William Anderson

Robert E. Cushman

Leonard D. White

John Gaus

Walter F. Dodd

Arthur W. MacMahon

Henry R. Spencer

Quincy Wright

James K. Pollock

Peter H. Odegard

Luther Gulick

Pendleton Herring

Ralph J. Bunche

Charles McKinley

Harold D. Lasswell

E. E. Schattschneider

V. O. Key, Jr.

R. Taylor Cole

Carl B. Swisher
Emmette S. Redford Charles S. Hyneman

Carl J. Friedrich

C. Herman Pritchett

David B. Truman

Gabriel A. Almond

Robert A. Dahl

Merle Fainsod

David Easton

Karl W. Deutsch

Robert E. Lane

Heinz Eulau

Robert E. Ward

Avery Leiserson

Austin Ranney

James MacGregor Burns

Samuel H. Beer

John C. Wahlke

Leon D. Epstein

Warren E. Miller

Charles E. Lindblom

Seymour Martin Lipset

William H. Riker

Philip E. Converse

Richard F. Fenno

Aaron B. Wildavsky

Samuel P. Huntington

Kenneth N. Waltz

Lucian W. Pye

Judith N. Shklar

Theodore J. Lowi

James Q. Wilson

Lucius J. Barker

Charles O. Jones

Sidney Verba

Arend Lijphart

Elinor Ostrom

M. Kent Jennings

Matthew Holden, Jr.

Robert O. Keohane

Robert Jervis

Robert D. Putnam

Theda Skocpol

Susanne Hoeber Rudolph

Margaret Levi

Ira Katznelson

Robert Axelrod

Dianne M. Pinderhughes

Peter Katzenstein

Henry E. Brady

Carole Pateman

G. Bingham Powell, Jr.

Jane Mansbridge

John H. Aldrich 